\title{
【解説】
}

\section{オープン MRI 下穿刺治療ナビゲーションロボットの制御 Control of Open MRI Compatible Needle Puncture Navigation Robot}

\author{
長縄明大 (正会員), 佐藤生馬 (非会員)*, 岡正人 (非会員)**, 正宗賢 $($ 正会員)**
}

Akihiro Naganawa, Ikuma Sato*, Masato Oka **, and Ken Masamune ${ }^{* *}$

\begin{abstract}
The surgical navigation robot is used in order to position the instrument correctly to the target disease. The development of a MRI (Magnetic Resonance Imaging) compatible navigation robot is recently started so as to utilize more rich information of the MR imaging. In this report, we discuss highly precise control of the navigation robot which is used under the MRI. This robot consists of ultrasonic motors (USM) and nonmagnetic materials. We operate the robot by using the phase difference control circuit which we developed as the driver of the USM. In a control system design, two-degrees-of-freedom control system was adopted. In addition, the MRI compatibility such as the skewness of the image and signal to noise ratio which we inspected using $0.2 \mathrm{~T}$ (Tesla) open MRI was evaluated. From the experimental results that imaged MR images while controlling the robot, we could realize the highly precise control and suppress the influence of the noise.
\end{abstract}

\section{Key Words}

open MRI, needle puncture navigation robot, ultrasonic motor, phase difference control

\section{1. はじめに}

近年, 医療用診断装置の画像を元にしたナビゲーション 情報の下で治療を行うナビゲーション手術が普及し始めてお り, 患部の位置や大きさと共に, 手術器具の位置や手術予定 の部位を視覚的に提示している. MRI は, 血管や神経の抽 出が容易であり, X 線 CT で問題となる骨の影響を受けず, 被曝の心配がないため, 術中に患部の診断結果やそれを元

2010 年 4 月 1 日受理

秋田大学大学院工学資源学研究科機械工学専攻, $\bar{\top}$ 010-8502 秋田市手形学園町 1-1

*東京大学大学院情報理工学系研究科知能機械情報学専 攻, 干113-8656 文京区本郷 7-3-1

**宇部工業高等専門学校機械工学科, $\bar{T} 755-8555$ 宇部市 常盤台 2-14-1

Akita University, 1-1 Tegata-gakuen-cho, Akita-shi 010-8502 Japan

* The University of Tokyo, 7-3-1 Hongo, Bunkyo-ku 113-8656 Japan

** Ube National College of Technology, 2-14-1 Tokiwadai, Ube-shi 755-8555 Japan
にしたナビゲーション情報を提供することができる．中でもオ ープン MRI は, 従来の MRI と撮像原理は同じであるが, 患 者撮影用の開口部が広く設計されており, 診断のみならず, 治療に利用できる空間を確保することができる. ${ }^{1-2)}$

そこで, 著者らは, MRI の持つナビゲーション情報を有効 に活用し，血管や神経を避けて針の刺入を行う穿刺治療に おいて, 定量的な位置決めを行うための MRI 対応穿刺治療 ナビゲーションロボットの研究開発を行っている. ${ }^{3-5)} こ の$ 目 的は, 術中に取得した患部の様子の MR 画像を術者にナビ ゲーション情報として提供し, また同時に穿刺作業の際の術 者の手ぶれを防止し, より精度の高い治療を可能とするため である. MRI 対応ロボットのアクチュエータには, 著者らが開 発した 6 軸穿刺ロボット以来 ${ }^{6)}$, 超音波モータ(USM)が多く 用いられているものの, 市販されている USM ドライバには, $3.14 \mathrm{rad} / \mathrm{sec}(30 \mathrm{rpm})$ 以下の速度制御を実現できないものが 多い. そのため, これが原因で目標位置近傍での高精度な 位置決めは困難となっている.

本稿では, 著者らが製作した USM の位相差制御用ドライ バを用いて, 穿刺治療ナビゲーションロボットの高精度制御 に焦点を絞り，0.2T オープン MRI 下における制御性能およ び MRI 対応性評価の結果について解説する. 


\section{2. 穿刺治療ナビゲーションロボット}

Fig. 1 に $0.2 \mathrm{~T}$ オープン MRI 下に設置したナビゲーション ロボットの写真を, Fig. 2 にロボットの構成図を示す.ナビゲ ーションロボットの役割は, 穿刺治療において重要である穿 刺針などの医療器具の位置決め, 刺入角度の決定と器具の 把持による手ぶれ補償であり, 穿刺そのものは安全のために 術者が行う. ナビゲーションロボットは, 14 自由度の非磁性空 気圧式パッシブアーム (Point Setter, Mitaka Kohki Corp.)により支持されており, 直動機構と回転機構の 2 自由 度を有している。

治療の際には, パッシブアームにより, Fig. 2 の ARM1 先 端部 B が刺入部付近に設置され, ARM2 が ARM1 に対し て相対的に動作することにより, その先端部 A を最終的な穿 刺方向を決定するように設置される. ARM1, ARM2 には, 先端に針をガイドするための小さな自在継手が取り付けてあ り, 穿刺治療は 2 つの継手を介して行われる. ARM2 は, USM1 と直動機構を組み合わせることにより伸縮し, USM2 と回転機構を組み合わせることにより回転する. 直動機構に

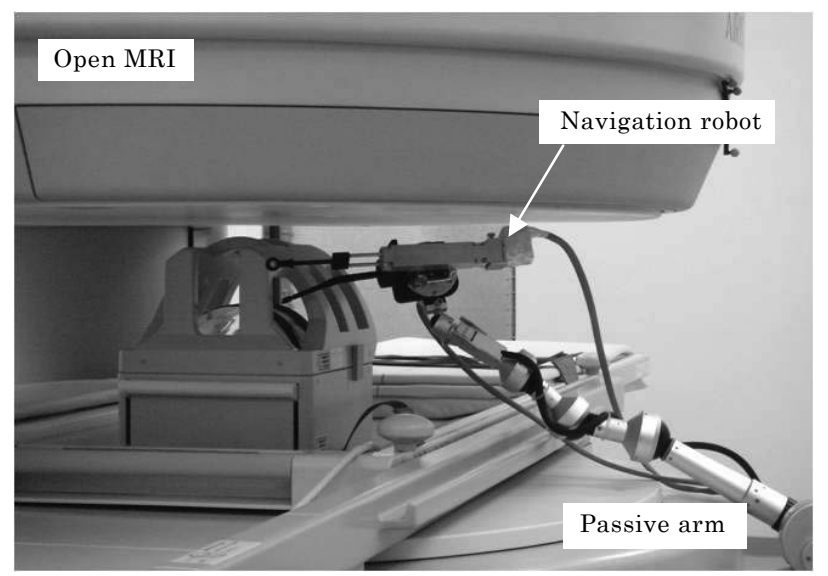

Fig. 1 Needle puncture navigation robot set up in open MRI.

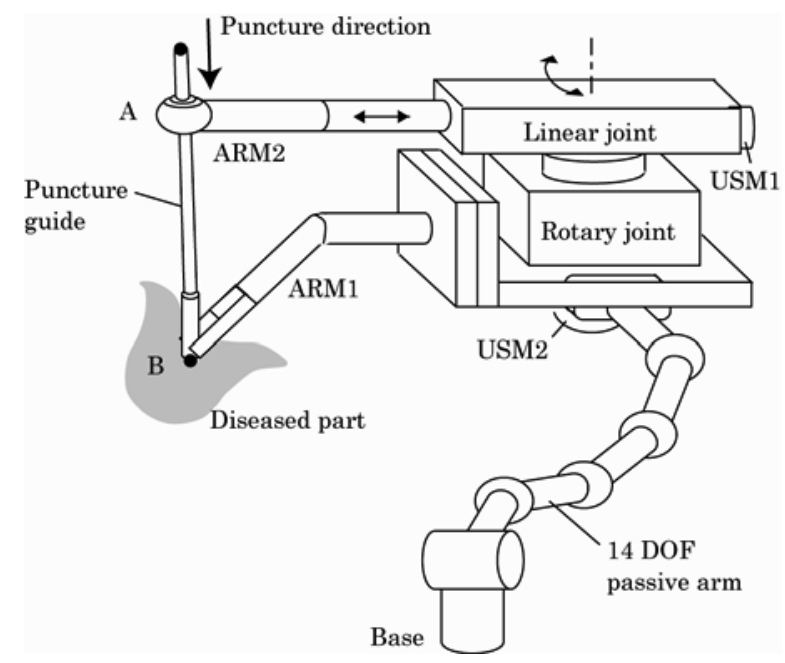

Fig. 2 Construct of navigation robot.
は非磁性送りねじ, 回転機構には精密減速機として非磁性 型ハーモニックドライブを使用したことにより, MRI の磁場に 影響を与えず高精度な位置決めが可能である. また, アーム 先端部は容易に着脱可能であり, アクチュエータ部に滅菌カ バーを掛けることにより, 術野の清潔を確保した機構となって いる.

Table 1 に機構の大きさ, 重さなどを示す. 直動機構の送 り分解能は $2.0 \times 10^{-3} \mathrm{~mm}$, 回転機構の分解能は $1.745 \times 10^{-4}$ rad であり, 高い精度を有している. 一方, Table 2 に使用し た要素とその材質を示す. 本ロボットは MRI 下で使用するた め, MR 画像に影響を与えない非磁性材の部品を選定した. また, 電磁モータはMRIガントリ内の強磁場環境下では動作 せず, 磁性体を用いたモータは MRI に引きつけられるため 危険である.このため, 非磁性材で製作されている USM を 選定したが, 駆動時には電流が流れ, 電磁波を放射する. MRI の共鳴周波数近傍にその電磁波が乗ると, 画像にノイ ズが加わるか画像が抽出されなくなるため, 電磁波対策が必 要である. 電磁波シールド材は数多くあるが, MRI 環境下で 使用するためには非磁性材でなくてはならない. そこで, USM のシールドには, 重ねることで容易にシールド効果の増 大が見込まれるアルミホイルを主に用いた.アルミホイルのシ ールド間に絶縁体のテープを用いて絶縁して固めることで多 重に遮蔽し, 全てのシールドに多点でアースを取り付け, シ ールド効果を増大させた. USM のケーブルは, 銅網編組ケ ーブルでシールドし, ケーブル長を $10 \mathrm{~m}$ としてドライバや PC などの制御装置をすべて MRI 室外に設置した。

Table 1 Size and resolution of the structure.

\begin{tabular}{|l|l|}
\hline \multicolumn{2}{|l|}{ Linear joint } \\
\hline $\begin{array}{c}\text { Size }[\mathrm{mm}] \\
\text { Height } \times \text { Width } \times \text { Length }\end{array}$ & $30 \times 30 \times 165$ \\
\hline Driving range [mm] & 70 \\
\hline Resolution of leed [mm] & $2.0 \times 10^{-3}$ \\
\hline Weight [g] & 246 \\
\hline Rotation joint & $80 \times 80 \times 105$ \\
\hline $\begin{array}{c}\text { Size [mm] } \\
\text { Height } \times \text { Width } \times \text { Length }\end{array}$ & $1.745 \times 10^{-4}$ \\
\hline Resolution of rotation [rad] & 440 \\
\hline Weight [g] & \\
\hline
\end{tabular}

Table 2 Elements and material of the robot.

\begin{tabular}{|l|l|}
\hline Element & Material \\
\hline Actuator and sensor & $\begin{array}{l}\text { Nonmagnetic USM, Shinsei } \\
\text { Corp. USR30E3N, } \\
\text { Rotary encorder 2000 [ppr] } \\
\text { (Quad edge evalution) }\end{array}$ \\
\hline Harmonic gear & Ceramic, SUS304 \\
\hline Plain bearing & Resin \\
\hline Screw and nut & PPS \\
\hline Feed screw & SUS304, Resin \\
\hline Bearing & Ceramics \\
\hline
\end{tabular}




\section{USM の速度特性}

USM は, 小型軽量, 低速高卜ルクであり, 作動音が小さく, 停止時の保持トルクが大きいなどの特徵を有している. また， USM は, 磁気作用を動作原理としていないため電磁ノイズを 発生せず, また MRI の高磁場による影響を受けないため, MRI ガントリ内で使用するマニピュレータなどの電磁モータが 使用できない医療福祉分野のアクチュエータとして期待され ている. しかし, USM は動作原理が摩擦駆動であり, その入 出力特性は本質的に非線形性を有する上, 摩擦熱による温 度上昇や負荷の変化により回転速度特性が大きく変動する.

USM の制御手法には，一般に振幅制御，周波数制御， 位相差制御方式があるが，振幅制御方式ではある值以上の 電圧を印加しなければ USM は回転しないため低速域に不 感帯を生じ, また周波数制御方式では周波数の増減に対し て大きなヒステリシス特性を生じることが報告されている. 7-8) このため, 本研究では, 位相差制御方式を採用した. 製作し た位相差制御回路は, シフトレジスタを用いたディジタル回路 で構成しており，位相差は一 割して, $0.0245 \mathrm{rad}$ 刻みで調節できる.

Fig. 3 は, USM を位相差制御する際の印加電圧の一例 を示している. (a)は位相差が $0 \mathrm{rad}$ の場合, (b)は+ח/2 rad の場合であり, 図ではつぎの Fig. 4 で決定した駆動周波数 が $51.2 \mathrm{kHz}$ のときの波形を示している. 図(a)より, 位相差が $0 \mathrm{rad}$ であるため, USM に印加した 2 つ波形が重なってお

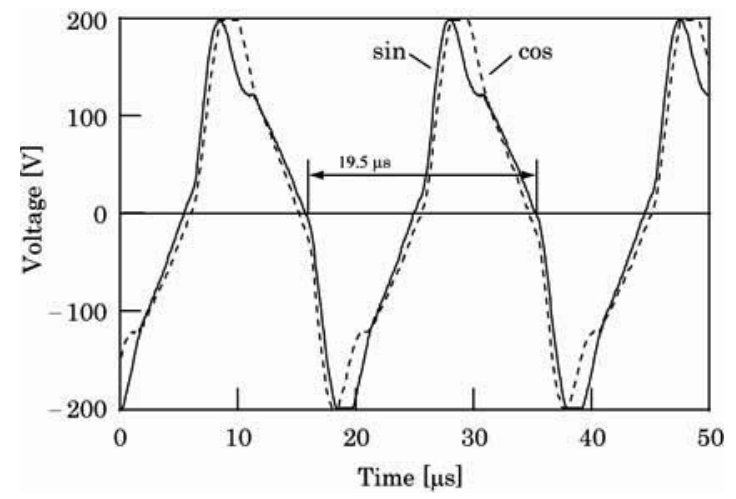

(a) Phase difference $0 \mathrm{rad}$

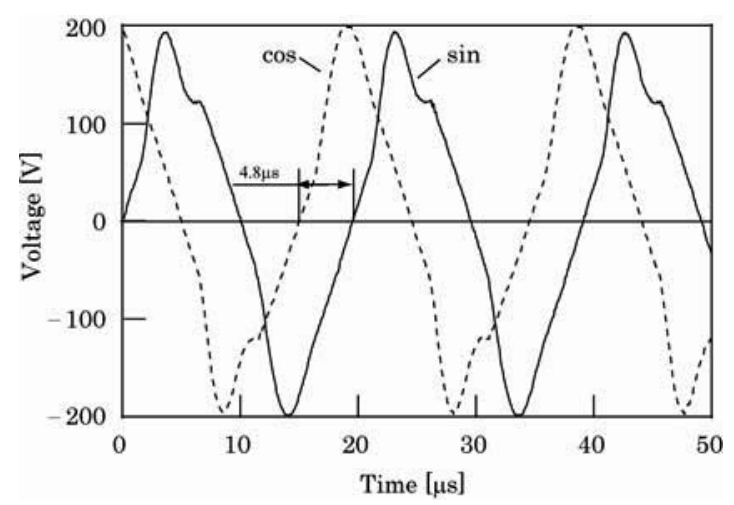

(b) Phase difference $+\pi / 2 \mathrm{rad}$

Fig. 3 Control signal for USM.
り，また周期が $1 / 51.2 \mathrm{kHz}=19.5 \mu \mathrm{s}$ であることがわかる. ま た, 図(b)より, 位相差が+ח/2 rad であるため, 2 つの波形が $1 / 4$ 波長, すなわち, $4.8 \mu \mathrm{s}$ ずれていることがわかる. 本研究 では,このように位相差を調整することにより, USM の速度制 御を行った。

2 章で述べたように, 本ロボットは, ARM2 が ARM1 に対し て相対的に動作することにより，最終的な穿刺方向を決定す るように設置される. ARM2 は, 2 つの USM により動作する ため, USM を高精度に制御し, 先端部を位置決めする必要 がある.このため, USM の駆動周波数を決定するため位相 差を十ா/2 radに固定し, 駆動周波数を変化させた場合の速 度特性を求めた. なお, 测定は USM をナビゲーションロボッ 卜に組み込み, 負荷を有する状態で行った. Fig. 4 に測定結 果を示すが, 以後の実験においても紙面の都合上, 回転機 構の結果のみを掲載する. 図より, USM2 は $50.5 \mathrm{kHz}$ のとき に最高速度を示しており, 駆動周波数を増加させるほど, 速 度特性が劣化していく様子がわかる.この結果より, USM2 の共振周波数は約 $50.5 \mathrm{kHz}$ と考えられるが, USM は摩擦 駆動方式であるため, 駆動時間が経過するとともに速度特性 が劣化する.このため, 駆動周波数は共振周波数より高めに 設定し, $51.2 \mathrm{kHz}$ として以下の実験を行った.

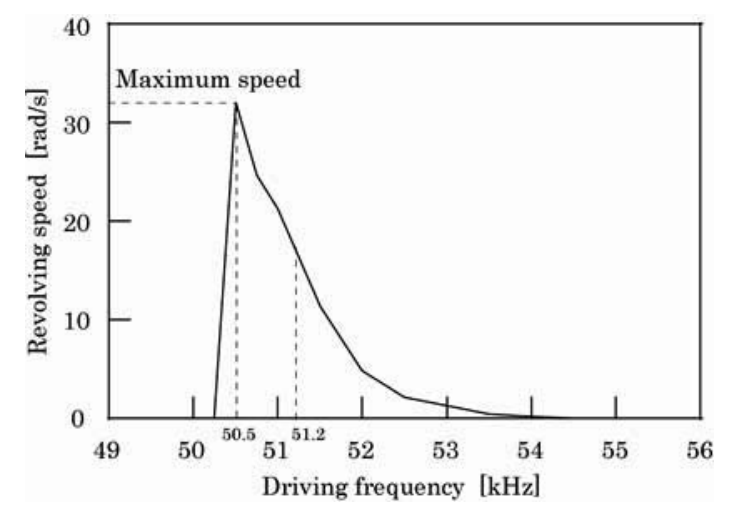

Fig. 4 A speed characteristic for driving frequency of USM2.

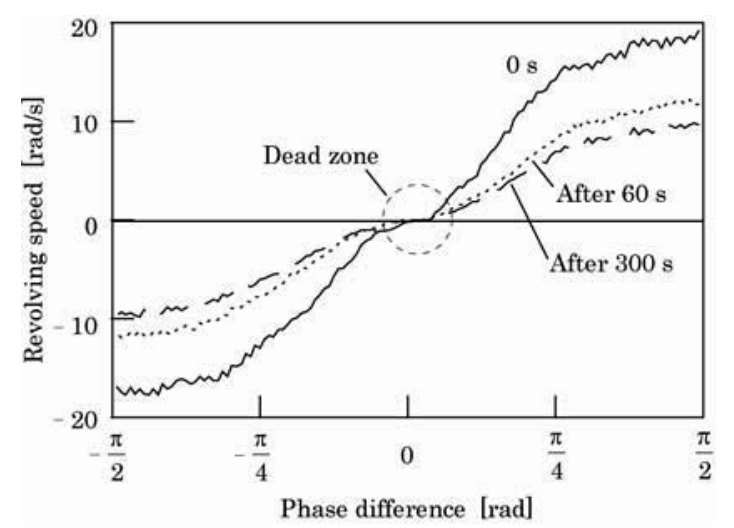

Fig. 5 A speed characteristic for phase difference of USM2. 
次に, Fig. 5 に位相差に対するUSM の速度特性を示す. 図中の 3 本の線は, 駆動直後 $0 \mathrm{~s}$, 駆動 $60 \mathrm{~s}$ 後, 駆動 $300 \mathrm{~s}$ 後の特性である. 図より位相差 $0 \mathrm{rad}$ 付近には, 位相差を変 えても速度が変化しない不感帯(Dead zone)が見られる.ま た，駆動時間が 60s，300s のように経過するにつれて速度特 性が低下していくことがわかる. しかし，このような不感帯の影 響や速度特性の低下はフィードバック制御により補償すること が可能である.

\section{4. 制御系の構成}

USMの高精度位置決め制御法については,これまで駆動 原理により生じる非線形性や摩擦熱の影響, 低速域に生じる 不感帯などを補償するため, 様々な手法が多く提案されてきた が, 確立された方法はない.7-10) そこで本研究では, 目標值 応答特性とフィードバック特性を独立して設計することができる 2 自由度制御系を採用し, フィードフォワードコントローラにより 望ましい目標值応答特性を実現し, フィードバックコントローラ により非線形性や摩擦熱の影響などを補償する手法について 検討を行った。

Fig. 6に本研究で用いた条件付き 2 自由度制御系のブロッ ク線図を示す. 11) ここで, $r$ は目標值, $v$ は規範モデル $F(z)$ の出 力, $u$ は位相差制御入力, $y$ はUSMの角度を表す.また, $P_{a}(z)$ は実際のUSM, $P(z)$ はUSMのモデルの伝達関数を表す.こ の制御系では, 制御対象にモデル化誤差がなく $\left(P_{a}(z)=P(z)\right.$ で ある場合), 外乱も存在しない場合には, 偏差eはゼロとなる. このとき, 目標值 $r$ から出力 $y$ への伝達関数 $G_{y r}(z)$ は,

$$
G_{y r}(z)=F(z)
$$

となり, 目標值応答特性は規範モデル $F(z)$ の出力に一致す る。一方，制御対象にモデル化誤差が存在する場合 $\left(P_{a}(z) \neq P(z)\right.$ の場合) や外乱が存在する場合には, 偏差 $e$ はゼ ロとならないため, このときフィードバックコントローラ $C(z)$ が動 作する. したがって, 変動や外乱の影響は, フィードバックコ ントローラ $C(z)$ で抑制するように設計できる.この制御系が安 定であるためには, $F(z)$ および $F(z) / P(z)$ が安定プロパな実有

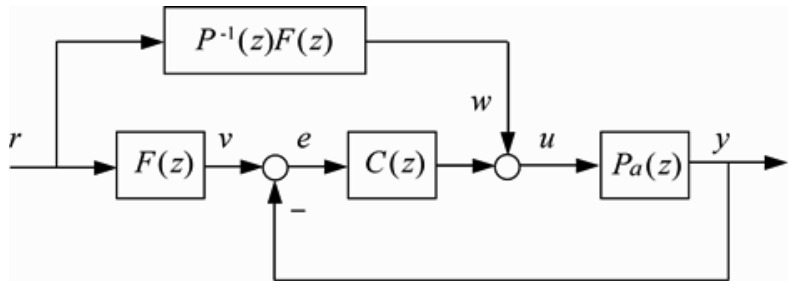

Fig. 6 Control system of USM.

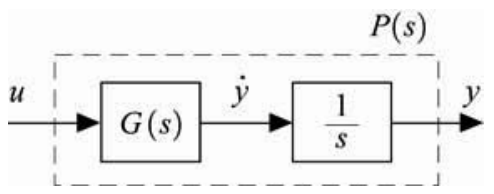

Fig. 7 USM model for precise control.
理関数, $C(z)$ が内部安定化補償器であれば良い. Fig. 7 は, $\mathrm{USM}$ のモデル $P(s)$ のブロック線図を示しており, 位相差制御 入力 $u$ から速度 $\dot{y}$ までの伝達関数を $G(s)$, 速度 $\dot{y}$ から角度 $y$ までの伝達関数を $1 / s$ とした. 伝達関数 $G(s)$ は, 位相差制御 入力 $u$ を 0 から $\mathrm{n} / 2 \mathrm{rad}$ に変化させたときの速度特性からつ ぎのように求めた。

$$
G(s)=\frac{K}{T s+1}
$$

ここで， $K=42 ， T=0.00746 \mathrm{~s}$ である. Fig. 6のブロック線図中の $P(z)$ は, $P(s)$ にゼロ次ホールドを前置し, サンプリング周期 $5 \mathrm{~ms}$ で離散化して求めた. なお, Fig. 4, 5に示すように直動機構も 回転機構とほぼ同じ速度特性を有していたため, 同じ制御系 を構成することができた。

フィードバックコントローラ $C(z)$ は, 次式で与えられるPIDコン トローラとした.

$$
C(z)=K_{P}+\frac{K_{I} z^{-1}}{1-z^{-1}}+K_{D}\left(1-z^{-1}\right)
$$

ここで, PID ゲインは, 試行錯誤により $K_{P}=3.0, K_{I}=0.5$, $K_{D}=1.0$ と決定した. 規範モデル $F(z)$ は, USM のモデル $P(z)$ の次数と過渡特性の立ち上がり時間を考慮し, 次式を離散 化した伝達関数とした。

$$
F(s)=\left(\frac{m}{s+m}\right)^{2}, \quad(m=2)
$$

Fig. 8に, USMを制御するためのハードウエア構成を示す。 Fig. 6の制御系はPC上に実装される. USMの角度情報yは， USMに取り付けられているロータリーエンコーダにより検出さ れ，エンコーダ回路を介してカウンタボードからPCに取り込ま れる.PCでは目標值を実現するように制御演算が行われ， DIOボードから制御に必要な位相差の指令が送られる. 位相 差回路では, PCからの指令に応じた位相を選択し, 昇圧回路 を介してUSMを駆動する.

\section{5. 制御実験の結果}

制御実験は, Fig. 1 に示すように $0.2 \mathrm{~T}$ オープン MRI のガ ントリ内にナビゲーションロボットを設置し, USM を駆動して 行った. 目標值 $r$ は, 振幅 $\pm 4.712 \mathrm{rad}$ を周期 $12 \mathrm{~s}$ で変化す る矩形波とした. Fig. 9 に実験開始直後から $72 \mathrm{~s}$ 後までの回 転機構のUSM の位置決め制御の結果を示す.図中の

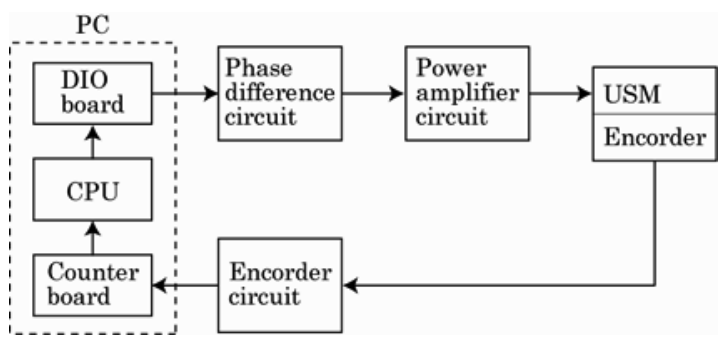

Fig. 8 Hardware configuration for USM control. 
点線は目標值 $r$ を, 実線は出力 $y$ (破線の規範モデルの出力 $v$ は出力 $y$ に重なっている)を示している. Fig. 4 より, 駆動直 後 $0 \mathrm{~s}$ と駆動 $60 \mathrm{~s}$ 後では USM の速度特性が大きく異なるが, Fig. 9 より, 本手法では USM の出力 $y$ は規範モデルの出力 $v$ に非常によく一致している様子がわかる.これは, 特性変動 や不感帯などの影響が, フィードバック制御により抑制されて いるためであるといえる.

Fig. 10 にSM2 の制御実験における駆動開始 70〜 72s の目標值近傍の拡大図を示す. エンコーダの分解能は 4 逓 倍処理を行い $2000 p p r$ としているため, 最小位置決め精度 は $3.14 \times 10^{-3} \mathrm{rad}$ となるが, 目標值近傍では最小分解能の

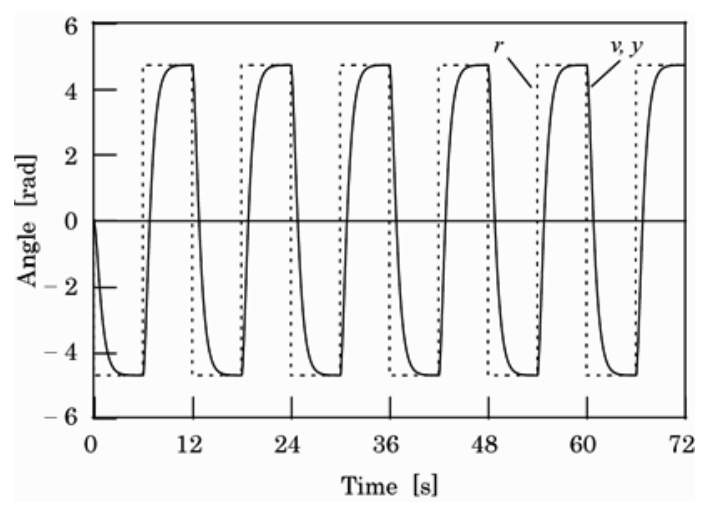

Fig. 9 Reference response characteristic of USM2.

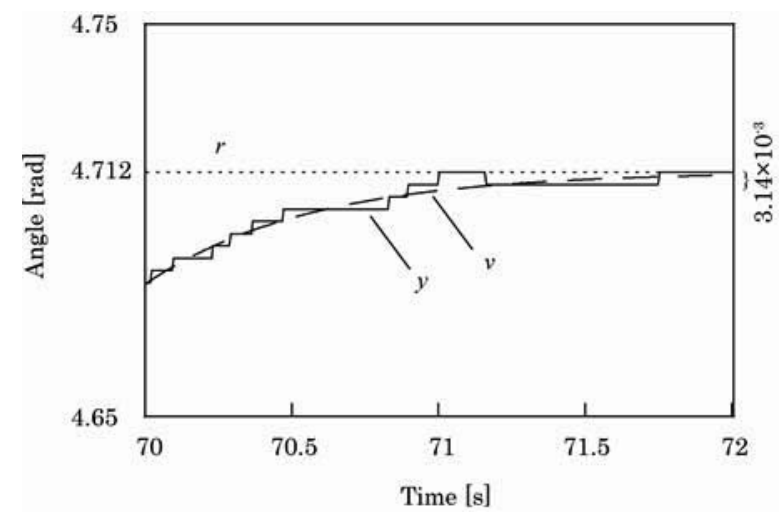

Fig. 10 Enlargement figure for Fig. 8 (USM2).

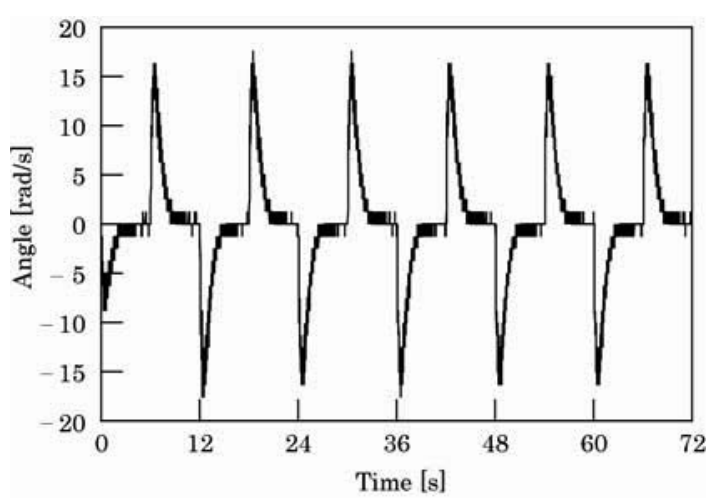

Fig. 11 Velocity property of USM2.
精度で位置決め制御を実現できた。

この場合のロボットの位置決め精度は，つぎの通りである. 直動機構は, 送りねじの分解能が $0.002 \mathrm{~mm}$ であるため, 結 果を省略しているが, USM の位置決め精度が $3.14 \times 10^{-3}$ $\mathrm{rad}$ であった場合, $1 \mu \mathrm{m}$ の精度で位置決めを実現することが できた. また，回転機構は, ハーモニックドライブの減速比が 1/100であるため, $3.14 \times 10^{-5} \mathrm{rad}$ の精度で位置決めを実現 することができた.いずれの結果も，これまで報告された MRI 対応マニピュレータより, 高精度な位置決め制御を実現して いる.

Fig. 11 に制御実験を行っている際の速度特性を示す. 図 より，市販ドライバでは実現できない $3.14 \mathrm{rad} / \mathrm{s}$ 以下の特性を 実現できていることがわかり，目標值近傍での高精度な位置 決めの際にはノイズの影響が見られるものの $0 \mathrm{rad} / \mathrm{s}$ になって いることがわかる。

\section{MRI 対応性の評価}

MRI 対応性の評価として, ロボットが MRI 画像に対して影 響を与えないこと, MRI の電磁環境がロボットに対して影響 を与えないことを検証する必要がある. 本ロボットは, 非磁性 材で構成されているものの金属を用いているため, 米国材料 試験協会 (ASTM12) ) による分類では”MR Conditional” に該当する.ここでは特に治療に直結する評価指標として, 前章の制御実験を行いながらロボットの動作が MR 画像に与 える影響について, 画像の歪みと $\mathrm{S} / \mathrm{N}$ 比により評価した. ${ }^{4)}$ 画 像の歪みと $\mathrm{S} / \mathrm{N}$ 比は, MR 画像の画質の評価を行うための指 標の一つとしてよく用いられている. 画像の歪みは MRI 評価 用ファントムのみの画像とロボットの動作時に撮像した画像の 差分の絶対值を求めたものを画像化し, 歪みの有無により評 価を行う.また, $\mathrm{S} / \mathrm{N}$ 比はファントム部の信号強度とファントム 周辺部のノイズの標準偏差の比によって求めることができ，こ の值を用いて画質の評価を行う.

受信コイルにはヘッドコイルを用い, その中に格子入り円 筒型 MRI 評価用ファントムを設置した. USM の位置制御を 行いながら, MR 画像は Gradient Echo 法により撮影し, 各 パラメータは TR/TE:600/11 ms, FOV:256 mm, スライス厚 $10 \mathrm{~mm}$, フリップ角:ח/2 rad とした. ${ }^{13)}$

撮像は, (1)ファントムのみの場合, (2)前節の USM の駆動 実験を行った場合で行い, その MR 画像の結果を Fig. 12 に示した. (1)と(2)で得られた画像から，(3)の差分画像を求 めた結果, 多少の画像のゆがみが生じていたものの, 穿刺に 使う領域であるアーム付近の画像 (図の左下部分) は歪んで いなかった. また, S/N 比は(1)が 118.0, (2)が 113.6 であり， ファントムのみの場合に比べて, $3.7 \%$ 低下した程度であった. $\mathrm{S} / \mathrm{N}$ 比の低下が数\%以内程度であれば, 肉眼での識別は困 難であり, 実用上問題にはならない結果であった。

\section{7. おわりに}

本研究では, 研究開発を行っている穿刺治療ナビゲーショ 


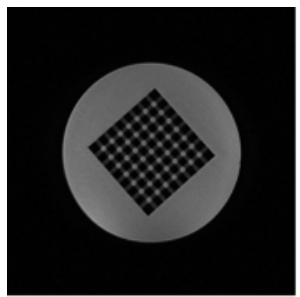

(1) Only phantom

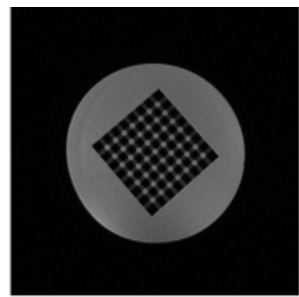

(2) USM driving

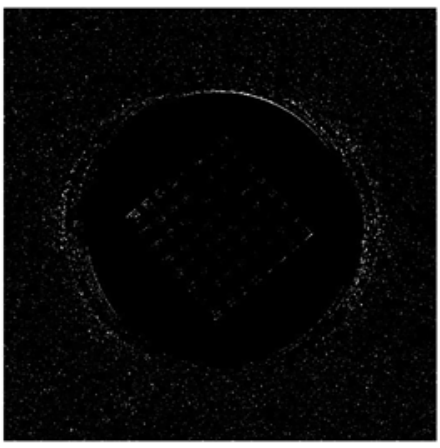

(3) Subtraction image

Fig. 12 MR images of phantom.

ンロボットの MRI 下での高精度位置決め制御について, 特 にUSM の高精度制御と MRI 対応性について焦点をあてて 述べた. 得られた結果をまとめると, 以下の通りである.

（1）著者らが製作した位相差制御用ドライバ回路および2自由 度制御方式を用いることにより, USMの出力は規範モデル の出力にほぼ一致し, センサの分解能まで高精度な位置決 めを実現することができた。

(2) MRI対応性の評価を行ったところ, 画像の歪み, S/N比の 低下は3.7\%でほとんど無く, 良好な結果が得られた。

本技術によって, USM の MRI 下での利用の適用拡大が 図られ, より高精度な治療が実現できるものと考えている.

\section{8. 謝辞}

本研究の一部は, 文部科学省科研費(\#18680042)による ものである. 本研究の実験に協力して頂いた秋田大学卒業 生の山尾拓也氏に感謝致します.

\section{参考文献}

（1）伊関洋, 村垣善浩, 中村亮一, 堀智勝, 高倉公朋, 杉浦 円, 谷口拡樹, 小沢紀彦, 白川洋, インテリジェントオペ 室・MRI 誘導手術対応システム. MEDIX, 2003;39 巻, pp.11-17.

（2）最上拓児, 土肥美智子, 原田潤太, 小村和美, 高橋哲 彦, 大井柾雄, 穿刺補助器具 Interactive Scan Control を使用したオープン MRl ガイド下凍結療法. Radiology Frontier, 2002; 5 巻, 1 号, pp.9-13.

(3) Hiroaki Naganou, Hiroshi Iseki, Ken Masamune, MRI Compatible Modular Designed Robot for Interventional Navigation - Prototype Development and Evaluation -, Lecture Notes in Computer Science (MICCAI2004) . 2004 ; pp.1069-1070.

（4）正宗賢, MRI 環境下における低侵襲手術支援システム. 日本機械学会誌, $2007 ; 110$ 巻, 1058 号, pp.15-18.

（5）正宗賢, 稲垣貴文, 高井信治, 鈴木真, MRI 環境下手 術支援用穿刺マニピュレータの開発および画像歪み計 測. 日本コンピュータ外科学会誌, $2001 ; 3$ 巻, 4 号, pp.273-280.

(6) Ken Masamune, Etsuko Kobayashi1, Yoshitaka Masutani, Makoto Suzuki, Takeyoshi Dohi, Hiroshi Iseki, Kintomo Takakura, Development of an MRI-Compatible Needle Insertion Manipulator for Stereotactic Neurosurgery. Computer Aided Surgery, 1995; Vol. 1, No. 4, pp. 242-248.

（7）千住智信, 宮里裕, 上里勝美, ハイブリッド制御による超 音波モ一夕の高速・精密位置決め制御。電気学会論文 誌, $1995 ; 115$ 巻 D, 11 号, pp.1333-1340.

（8）千住智信, 與古田覚, 上里勝美, 不感帯補償を有する 超音波モー夕の位置制御. 電気学会論文誌, $1999 ; 119$ 巻 D, 4 号, pp.494-500.

（9）千住智信, 宮里裕, 上里勝美, ハイブリッド制御による超 音波モータの高速・精密位置決め制御。電気学会論文 誌, $1995 ; 115$ 巻 D, 11 号, pp.1333-1340.

（10）福田耕司, 鎌野玩也, 鈴木茂行, 安野卓, 原田寛信, 周波数および位相差ニューラルネットワークを用いた超音 波モータ位置サーボシステムの高精度化. 日本 AEM 学 会, $1998 ; 6$ 巻, 4 号, pp.350-357.

（11）杉江利治，藤田政之，フィードバック制御入門. 1999; コロナ社, pp.168.

(12) http://www.astm.org/index.shtml

（13）荒木力, 杉村和朗 (編), MRI・CT 用語辞典, メディカ ルビュー社. 2000. 